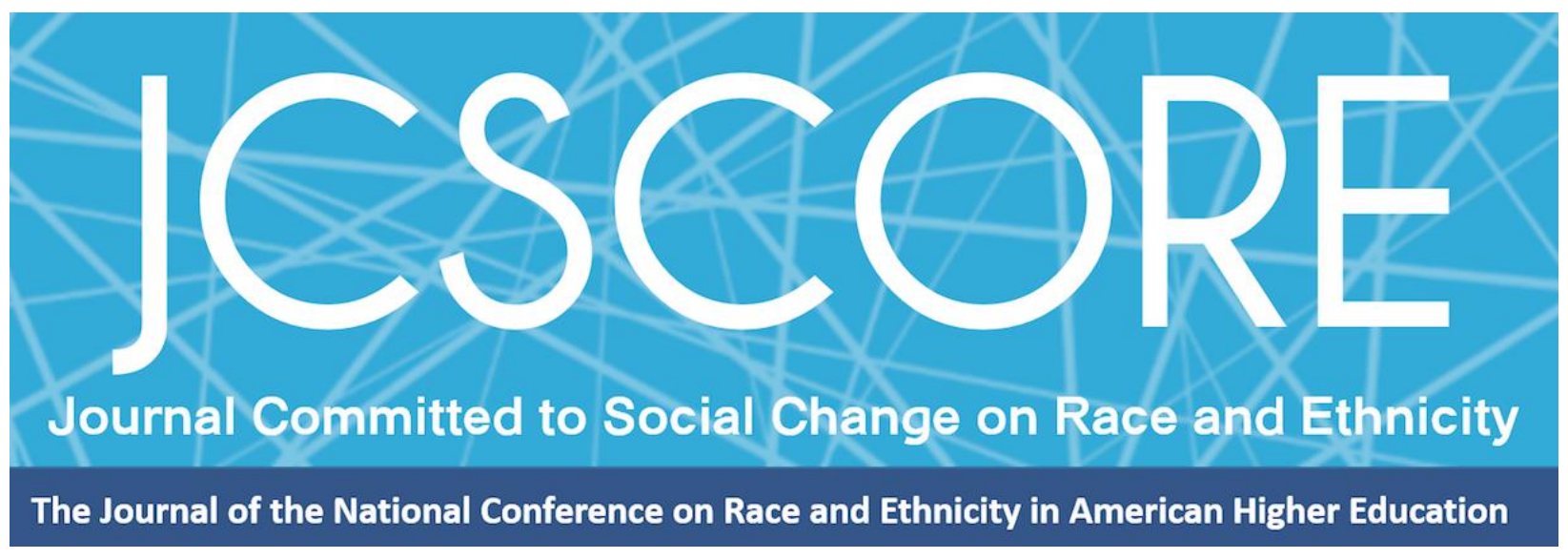

\title{
A WHITENED RAINBOW: THE IN/VISIBILITY OF RACE AND RACISM IN LGBTQ+ HIGHER EDUCATION SCHOLARSHIP
}

\author{
Romeo Jackson \\ Black Youth Project 100 \\ Alex C. Lange \\ Colorado State University \\ Antonio Duran \\ Florida International University
}

Journal Committed to Social Change on Race and Ethnicity

Volume 7, Issue 2 | 2021

\author{
Copyright and Open Access \\ (C) 2021 Romeo Jackson, Alex C. Lange, Antonio Duran

\section{(c) (i) (2) (2)}

This work is licensed under a Creative Commons Attribution-NonCommercial-ShareAlike 4.0 International License. Permission of the authors is required for distribution and for all derivative works, including compilations and translations. Quoting small sections of text is allowed as long as there is appropriate attribution and the article is used for non-commercial purposes.

The Journal Committed to Social Change on Race and Ethnicity (ISSN 2642-2387) is published by the National Conference on Race and Ethnicity (NCORE), a production of the University of Oklahoma, in partnership with the University of Oklahoma Libraries. 
Journal Committed to Social Change on Race and Ethnicity | Volume 7, Issue 2 | 2021

\title{
A Whitened Rainbow: The In/visibility of Race and Racism in LGBTQ+ Higher Education Scholarship
}

\author{
Romeo Jackson \\ Black Youth Project 100 \\ Alex C. Lange \\ Colorado State University \\ Antonio Duran \\ Florida International University
}

\begin{abstract}
Scholars critique LGBTQ+ social movements for failing to understand how oppressive systems like racism inform the experiences of LGBTQ+ community members. To investigate whether LGBTQ+ literature in postsecondary education reproduces this same pattern, we used a critical summative content analysis approach to examine research published on LGBTQ+ people between 2009 and 2019. Guided by a conceptual framework mobilizing notions of colorblindness and queer of color perspectives, we found that the 97 articles in the sample largely minimized the role that racism, anti-Blackness, whiteness, and settler colonialism plays in shaping LGBTQ+ realities in higher education. Implications for future scholarship are offered.
\end{abstract}

LGBTQ+ people have received greater attention in higher education literature over the past few decades. Researchers attribute this widening of scholarship to the growing culture of acceptance in the United States and abroad (Lange et al., 2019; Rankin et al., 2019). This increase in literature includes research about LGBTQ+ populations broadly as well as fewer studies that center queer and trans individuals who experience multiple forms of oppression (Duran et al., 2020; Lange et al., 2019). In particular, scholars have given more consideration to queer people of color (Duran, 2019). Simultaneously, researchers have started to make important interventions at the intersection of trans-ness and race (e.g., Jourian \& McCloud, 2020; Nicolazzo, 2016). Although this rise in literature attending to LGBTQ+ people with multiple minoritized 
Journal Committed to Social Change on Race and Ethnicity | Volume 7, Issue 2 | 2021

identities has the potential to positively impact the lives of these individuals, LGBTQ+ scholarship in higher education still focuses largely on the experiences and development of those most privileged within these communities (Lange et al., 2019).

This trend in literature mirrors the aims and goals of LGBTQ+ human rights organizations that have advocated for particular forms of legal rights (Conrad, 2014). Of note, the larger movement for LGBTQ+ equality has largely lacked a racial lens when considering the needs of all queer and trans people (Vaid, 2012); instead, the larger movements of the past decade have centered white, cisgender, heteronormative discourses of what it means to be queer or trans (Conrad, 2014; Krutzsch, 2019). Given the breadth of scholarship that now exists-and its comparisons to this national discourse-it is critical for scholars to examine the ways researchers think about, conceptualize, and carry out their studies of LGBTQ+ people in higher education (Duran et al., 2020). In other words, how have scholars taken up or rejected formations of what it means to be queer and trans in the literature? Given this point of inquiry, we as authors felt it important to examine how research about LGBTQ+ people in higher education considers and engages race and racism as a central influence in the lives of LGBTQ+ people.

Therefore, the purpose of this summative content analysis (Krippendorff, 2004; Neuendorf, 2017) that employed a critical approach was to examine how race and racism showed up in LGBTQ+ research in higher education. With colorblindness (Bonilla-Silva, 2014) and queer of color theoretical perspectives (e.g., Ferguson, 2004; Johnson \& Henderson, 2005) functioning as a conceptual framework, two questions guided our study: 1) How is race and racism used in LGBTQ+ research in the field of 
Journal Committed to Social Change on Race and Ethnicity | Volume 7, Issue 2 | 2021

higher education? And, 2) what implicit or explicit messages may be sent through this use and framing in queer and trans research?

Scholars and academic journals will benefit from the results since they will guide future considerations of how people frame and design their studies on queer and trans communities. Specifically, we contend that how LGBTQ+ researchers frame their scholarship has a significant impact on the ways that higher education institutional agents support LGBTQ+ communities.

\section{Setting the Stage: Race, Racism, and Whiteness in Higher Education Scholarship}

Scholars have studied the ways research often fails to attend to the role of race, racism, and white supremacy in higher education (Cabrera et al., 2017; Harper, 2012; Johnston-Guerrero, 2017; Patton et al., 2015). For instance, articles that focus on matters of race are oftentimes a small percentage of the overall publications in academic journals specific to the higher education field (Mitchell et al., 2014). However, it is not simply that there is a small number of articles centering a racial analysis that is the issue, but that these studies do not address the structures of oppression connected to race (Harper, 2012). The reality that scholarship in higher education regularly erases the presence of issues such as systemic racism, settler colonialism, and anti-Blackness is not surprising ${ }^{1}$. In fact, as Patton (2016) argued, racism permeates the historical and contemporary functions of postsecondary institutions, as well as the knowledge generating that occurs within them. To maintain the dominance of whiteness and white

\footnotetext{
${ }^{1}$ Although it is beyond the scope of this paper to define concepts like race, racism, settler colonialism, and anti-Blackness, we encourage readers to reference the following scholarship as it has long guided our thinking about these ideas: race (Omi \& Winant, 2015), racism (Bonilla-Silva, 2014), settler colonialism (Tuck \& Yang, 2012), and anti-Blackness (Dumas, 2016).
} 
Journal Committed to Social Change on Race and Ethnicity | Volume 7, Issue 2 | 2021

norms, scholars produce knowledge by rendering invisible any mention of oppressive systems like racism.

For instance, researchers have investigated scholars' attention to race and racism in postsecondary scholarship (Harper, 2012; Johnston-Guerrero, 2017; Patton et al., 2015). What these researchers revealed is how individuals frame their studies and engage in analysis prove to obscure the presence of racism. In his analysis of 255 articles published in higher education journals between 1999-2009, Harper (2012) found higher education researchers minimized racism as an institutional norm through research, finding that these scholars failed to interrogate the ways racism (and by extension race) shaped the experiences of students of color in higher education. Johnston-Guerrero (2017) then extended Harper's key argument by outlining how race gets used, operationalized, and interpreted in research on college students. In examining 261 studies focused on the study of college students, Johnston-Guerrero (2017) noted that his "review demonstrates how the methodological decisions scholars make may actually be racist" (p. 29). Notably, the choices on who to include in a racial analysis and to what end the racial analysis serves itself produce racist norms in postsecondary scholarship.

Nevertheless, perspectives on race and racism in higher education literature also emphasize the need to examine the multiple other discourses present in these systems (Cabrera et al., 2017; Harris \& Patton, 2019). For example, the work of Cabrera et al. (2017) underscored how whiteness manifests is not attended to in higher education research. They perceived this pattern occurring in bodies of literature showcasing interpersonal interactions, as well as in analysis on institutional structures. Similarly, 
Journal Committed to Social Change on Race and Ethnicity | Volume 7, Issue 2 | 2021

Harris and Patton (2019) underscored the need to further racial justice in higher education scholarship by mobilizing frameworks such as intersectionality in order to understand "the confluence of power, privilege, and whiteness" (p. 361). Inherent to this statement is the critique that research on race in postsecondary education has not substantially investigated the complexities in this analysis. Relatedly, scholarship on racism has not largely taken up anti-Blackness and settler colonialism (Stewart, 2019a).

Relevant to this present study, researchers have begun to name the presence of race and racism in LGBTQ+ higher education scholarship. For example, in her formative piece on the state of LGBT and queer research, Renn (2010) argued that most of the studies up to that point functioned in a way where "White, able-bodied, and middle-class are assumed norms" (p. 135). Of note, as mentioned previously, the literature on LGBTQ+ individuals in postsecondary settings has expanded to include and/or focus on samples of LGBTQ+ people of color (Duran, 2019; Lange et al., 2019; Rankin et al., 2019). However, scholars have simultaneously called attention to the lack of frameworks mobilized in these studies that attend to LGBTQ+ people of color and their experiences of oppression, including racism (Duran et al., 2020; Lange et al., 2019). Therefore, in order to move the study of LGBTQ+ individuals forward in the field of higher education, it is necessary to critically examine how race, racism, and other constructs like whiteness, anti-Blackness, and settler colonialism are taken up in postsecondary research.

\section{Conceptual Framework}

To frame the study, we paired a colorblind framework (Bonilla-Silva, 2014) with queer of color theoretical perspectives (e.g., Ferguson, 2004; Johnson \& Henderson, 
Journal Committed to Social Change on Race and Ethnicity | Volume 7, Issue 2 | 2021

2005). Colorblind racism as an ideology positions racial inequality as anything but racism (Bonilla-Silva, 2014). Four frames make up the colorblind framework: abstract liberalism; naturalization; cultural racism; and minimization of racism. First, abstract liberalism refers to a belief system where one opposes race-conscious measures to address discrimination while espousing beliefs that sound reasonable and moral. Second, naturalization includes beliefs that racial differences naturally occur. Third, the cultural racism frame relies on culturally based arguments to explain racial differences in society. Specific to this analysis, we focus on the fourth frame: the minimization of racism. This frame names how people reduce the role racism plays in society; in this way, "discrimination is no longer a central factor affecting minorities' life chances" (Bonilla-Silva, 2014, p. 77). Some individuals use this framework to reference racial progress - as measured by time - to articulate how racial discrimination exists but to lesser degrees in modern society. Through this frame, people pay less attention to the effects of racism and more to one's intentions, minimizing how individuals and institutions discriminate against people of color. Thus, the frame provides a useful lens to examine the existing scholarship and the way scholars do or do not take up race and racism as points of analysis.

In addition to colorblindness, we incorporated queer of color perspectives, suggesting that LGBTQ+ communities themselves have not been removed from the effects of colorblindness. Queer of color critique argues that the study of race, sexuality, and class has not been thoroughly interrogated in academic disciplines (Ferguson, 2004). These perspectives draw attention to the ways racism, heterosexism, and trans oppression - and thus race, sexuality, and gender identities - co-constitute one 
Journal Committed to Social Change on Race and Ethnicity | Volume 7, Issue 2 | 2021

another. The intersection of these identities produces certain livelihoods and life chances for individuals that scholars must give better attention to in research (e.g., Nguyen, 2014; Snorton, 2017), particularly higher education studies. Moreover, queer of color perspectives show the ways that white queer theory has erased Blackness (Johnson \& Henderson, 2005), emphasizing the importance of settler colonialism in theorizing gender and sexuality (Driskill, 2016) and race/ism (Cohen, 1997) more broadly. Applied to education research, queer of color perspectives highlight the intersectional experiences of marginalization of queer students of color in schooling contexts (Brockenbrough, 2015). Queer of color critique opens an analytic space to think through the ongoing erasure of race and racism in LGBTQ+ scholarship while centering the lives of LGBTQ+ people of color. As our conceptual framework, these analytical perspectives help us interrogate how scholars do (not) take up racial analysis in their studies of LGBTQ+ students and the effects of potential evasions within the past decade.

\section{Study Design}

We employed a critical approach to summative content analysis to answer our research questions (Krippendorff, 2004; Neuendorf, 2017). A branch of content analysis, summative content analysis methodology identifies the frequency of concepts in a given text or set of texts and then interrogates the ways these concepts-and their associated terms-come to communicate specific meanings. Scholars have used summative content analysis to analyze peer-reviewed journal articles in their effort to understand the meanings and interpretations of concepts embedded in articles of interest (e.g., Hsieh \& Shannon, 2005; Harris \& Patton, 2019). However, in this study, 
Journal Committed to Social Change on Race and Ethnicity | Volume 7, Issue 2 | 2021

we followed the lead of researchers like Kortegast et al. (2020) who mobilized summative content analysis toward critical ends. Namely, critical summative content analysis allowed us to comprehend not only how commonly constructs and ideas appeared, but also how these patterns reveal larger insights about how power operates in a given study.

\section{Data Collection}

Informed by similar studies investigating the use of race-conscious frameworks, we selected eight journals credited as those that publish the top tier of higher education scholarship on college students (Harper, 2012; Harris \& Patton, 2019). These journals were Community College Review, the Community College Journal of Research and Practice, the Journal of College Student Development, the Journal of Diversity in Higher Education, the Journal of Student Affairs Research and Practice, The Journal of Higher Education, Research in Higher Education, and The Review of Higher Education. We also heeded Graves's (2018) point that much LGBTQ+ scholarship - in her case, educational historical articles - does not appear in discipline-based journals given the lack of acceptance of topics amongst scholars. To that end, we included three journals that commonly publish LGBTQ+ - related education scholarship: the Journal of Homosexuality, Journal of LGBT Youth, and TSQ: Transgender Studies Quarterly.

We utilized electronic retrieval sources to find articles published between January 1, 2009, and December 31, 2019. The eleven-year mark was selected given the shifting social and political landscape for LGBTQ+ people and the increase in higher education scholarship (Lange et al., 2019). To be included in the sample, a manuscript had to (1) report findings from an empirical study and (2) contain samples of queer and trans 
Journal Committed to Social Change on Race and Ethnicity | Volume 7, Issue 2 | 2021

people. We first scanned titles and abstracts to determine the inclusion or exclusion of a study in the sample. If it was still unclear whether the article fit into the sample, we read the full article. Each member of the research team brought articles to the group that they were unsure of, and a group decision was made. In sum, we located 97 articles that aligned with the criteria and made up the sample for this study.

\section{Data Analysis}

Informed by Harris and Patton (2019) who similarly employed a summative content analysis approach, we created a 20 -question rubric to begin our data analysis. Specifically, we sought to understand and categorize how authors used, or named, race and racism in relation to queer and trans people in higher education (see Table 1). We developed these questions guided by our conceptual framework that placed conversations of colorblindness (Bonilla-Silva, 2014) together with queer of color perspectives (e.g., Ferguson, 2004; Johnson \& Henderson, 2005). Additionally, we included questions employed in Johnston-Guerrero's (2017) study, which interrogated the application of racial constructs in college student research. The three researchers then divided the journal articles and read the manuscripts in their totality. While reading the 97 articles, we filled out a rubric for each article using a shared spreadsheet. We included both direct quotes and summary comments relevant to each question.

After this step was complete, we individually reviewed all rubrics to notate how often certain concepts (e.g., racism, whiteness, anti-Blackness) appeared in the articles to align with our summative content analysis approach (Hsieh \& Shannon, 2005) and guided by our critical lens. After reviewing each rubric, we came together and shared the patterns that we noticed most from the data set. In this conversation and in 
subsequent ones, we moved toward what is referred to as latent content analysis, which involves understanding how the patterns we discovered hold underlying meanings (Hsieh \& Shannon, 2005). Specifically, we recognized that the trends that we had noticed about how often particular concepts appeared communicated implicit messages about how authors perceived the relevance of constructs such as race and racism among others. These debriefing discussions then led us to develop themes highlighted in our findings.

Table 1. Rubric Questions and Criteria

\begin{tabular}{|l|l|}
\hline Paper Component & Questions \\
\hline Type of Study & $\begin{array}{l}\text { Qualitative? } \\
\text { Quantitative? } \\
\text { Mixed-Methods? } \\
\text { Other? }\end{array}$ \\
\hline $\begin{array}{l}\text { Theoretical/Conceptual } \\
\text { Framework }\end{array}$ & $\begin{array}{l}\text { Attentive to race and/or racism? } \\
\text { Settler-colonialism named? } \\
\text { Anti-Blackness named? }\end{array}$ \\
\hline Race in Study Set-Up & $\begin{array}{l}\text { Was race brought up in the literature review? } \\
\text { In the conceptual or theoretical framework? }\end{array}$ \\
\hline Racism in Study Set-Up & $\begin{array}{l}\text { Was racism brought up in the literature review? } \\
\text { In the conceptual or theoretical framework? }\end{array}$ \\
\hline Applications of Race & $\begin{array}{l}\text { (Enumeration) Was race and/or ethnicity used to describe sample } \\
\text { characteristics? } \\
\text { (Comparative) Was race and/or ethnicity used to compare different groups } \\
\text { in the sample? If used, does the study contextualize racial differences in the } \\
\text { data, if any? } \\
\text { (Collapse) Were students of color collapsed into one group? If so, what } \\
\text { rationale did authors provide, if any? } \\
\text { (White) Was "white" named as a race in the study? } \\
\text { (Control) Was race and/or ethnicity used as a "control" in statistical } \\
\text { analysis? If so, what reasoning did the authors provide, if any? }\end{array}$ \\
\hline $\begin{array}{l}\text { Analysis, Findings, and } \\
\text { Discussion }\end{array}$ & $\begin{array}{l}\text { Was "whiteness" included in the analysis? If so, how was it defined, if at all? } \\
\text { How does race get brought up in the study findings and discussion? } \\
\text { How does racism get brought up in the study findings and discussion? }\end{array}$ \\
\hline How does race get brought up in the study implications? \\
How does racism get brought up in the study implications?
\end{tabular}


Journal Committed to Social Change on Race and Ethnicity | Volume 7, Issue 2 | 2021

\section{Positionality and Reflexivity Statements}

Understanding that who we are as queer people and as researchers invested in queer and trans research are not separate; we first provide a group positionality and reflexivity statement then as individuals. We combine positionality and reflexivity statements to do more than simply give a list of identity markers that are decontextualized. Rather, we give insights into our political and epistemological stances by naming how our lives, theoretical underpinnings, and identities shaped our approach (Jones et al., 2014). As a group, we are committed to how race and racism shape the lives of LGBTQ+ people because we are invested in the liberation of all LGBTQ+ people. Moreover, as critical scholars, we assert the lives of LGBTQ+ people cannot be removed from conversations of interlocking systems of power, oppression, and privilege.

Romeo is invested in understanding how discourses create possibilities or limitations for queer and trans people of color. Informed by Black feminist, queer, and trans theories, Romeo was attentive to how queer and trans people of color experiences were (not) framed with attention to race and racism. Moreover, as a Black, queer, femme, Romeo was aware of the unique ways anti-/Blackness are rendered invisible in LGBTQ+ research.

Alex maintains their interest and investment in interrogating dominance and Whiteness in student affairs research and practice. Given their history as an LGBTQ+ resource center professional and social location as a white/multiracial, genderqueer, queer person, Alex centers those on the margins of campuses in their work while interrogating the forces placing students on the margins. For this study, Alex paid 
Journal Committed to Social Change on Race and Ethnicity | Volume 7, Issue 2 | 2021

attention to how researchers named Whiteness in studies and resulting effects on queer and trans students of color.

Antonio initially reflected upon his salient identities as a cisgender queer Latino man. In particular, as a queer person of color, Antonio is particularly passionate about uplifting the voices of trans and queer communities of color in higher education. This lens was evident throughout this study, as he was particularly interested in how scholars attended to interlocking structures of domination in LBGTQ research.

Findings

There are several findings related to race and racism that emerged from our study: The Use of Race-Explicit Frameworks; (Lack of) Naming Race and Racism; Calls for Future Research; and Understandings of White and Whiteness. To illustrate these findings, we provide examples from the studies that we surveyed and use direct quotes when applicable, but do not note where the articles were from originally. This choice aligns with our framework as it shows how issues of colorblindness are emblematic of larger discourses rather than being isolated to specific instances and authors. This practice parallels similar research investigating matters of race and racism in the literature (see Harper, 2012; Harris \& Patton, 2019).

\section{The Use of Race-Explicit Frameworks}

Resisting colorblind rhetoric (Bonilla-Silva, 2014), we define "race-explicit frameworks" as ways of knowing that trace patterns of race and racism in their conceptualization of material, social, and discursive realities. Of the 97 articles reviewed, only 21 used race-explicit frameworks that were created to spotlight racerelated patterns, as well as expose how racism operates in context. Of race-explicit 
Journal Committed to Social Change on Race and Ethnicity | Volume 7, Issue 2 | 2021

frameworks used, intersectionality was the most used framework, appearing six times, followed by Black queer/quare theory which appeared four times. Of note, two scholars used frameworks we as authors know to be attentive to race but were not named as such. As mentioned in our methods section, if race or racism was not explicitly named in the article, we did not consider it to be a race-explicit framework, given our interest in how authors named race and racism in relationship to their theoretical approach. For example, one author invoked intersectionality (Crenshaw, 1989) as the theoretical framework for their study examining the experiences of UndocuQueer students. The author drew on intersectionality to interrogate how citizenship/immigration and queerness overlaps. Drawn from critical race and legal studies, intersectionality, in part, sought to intervene into legal discourses that rendered Black women invisible in antidiscrimination laws due to the combination of racism and sexism (Crenshaw, 1989). To be sure, there are ongoing debates if the use of intersectionality always requires attention to racism as well as, how scholars mis/use intersectionality (Harris \& Patton, 2019; Nash, 2019). Nevertheless, in this circumstance, the author did not take up an analysis of how race and racism would be present in his study.

In another example, a scholar used Critical Trans Politics (CTP; Spade, 2011) when articulating the experiences of trans students. CTP, as put forth by Spade, is within the lineage of critical race theory (Spade, 2011). In their work, Spade is clear about CTP's attention to racism and settler colonialism in the regulation of possibilities for trans people within what is currently called the United States (Spade, 2011). And yet, in the article reviewed for this content analysis, the researcher did not substantially attend to CTP's history as tied to critical race theory while introducing the framework. 
Journal Committed to Social Change on Race and Ethnicity | Volume 7, Issue 2 | 2021

Indeed, what was evident from these patterns is that authors may draw from some tenets of theories while disregarding others. However, given the ways that attention to racism is core to both intersectionality and CTP, it was troubling to see a lack of naming the race-explicit foundations of frameworks used within these two studies.

Of the 21 articles that used race-explicit frameworks, none named anti-Blackness and/or settler colonialism as a structure informing the research. For example, in a study examining the experiences of Black gay and bisexual men, the author used quare theory as their framework. The author employed "quare theory as a conceptual framework to understand the intersectionality of race and sexuality during student participants' spiritual journey." In this example, even as the author mobilized a raceexplicit and a Black-specific framework, anti-Blackness went unnamed. Given the ways higher education is historically and currently shaped by the on-going legacy of antiBlackness (Dancy et al., 2018; Wilder, 2013) and settler colonialism (Lee et al., 2020; Stein, 2020), this finding is concerning.

\section{(Lack of) Naming Race and Racism}

Another pattern that emerged in this study is how researchers lacked attention to race and racism as they interpreted their data (e.g., participant quotes, statistical findings). This lack of attention occurred even when participants themselves named racism. In three separate instances, authors included a direct quote in their findings where participants mentioned racism; the authors did not expand upon the participant's discussion of the issue or give it analytical attention. For example, in one study, a participant explained:

It's when you refuse to learn, and disregard education, and disregard the opportunity to ask questions or to learn from some of those opportunities, that's 
Journal Committed to Social Change on Race and Ethnicity | Volume 7, Issue 2 | 2021

when it leads to that racism and homophobia because you don't care, you don't want to know.

In context, this quote was in response to researchers asking about ways that participants educated straight fraternity men about sexual orientation. Following this quote, the authors went on to unpack the nuance of using personal interactions to address homophobia. Yet, this same attention was not giving to racism, privileging an analysis of homophobia. It is hard to say why an author would include a direct quote mentioning racism without expanding on it. However, for this participant, there is some connection between racism and homophobia that goes unexamined.

Additionally, scholars tended to name social identities other than gender and sexuality, but it was coupled with a lack of critical engagement in data collection, analysis, and interpretation. For example, researchers studying LGBTQ+ people may have acknowledged the presence of other social identities, such as race and class, when listing the demographics of participants. Yet, there was often little to no engagement with these other social identities in the analysis of the study. Take, for example, an instance in which the authors named the percentage of the sample that are students of color without expanding on how this impacts the overall study, "Over $30 \%$ of the participants in this sample identified as students of color, however it is unclear how their racial identities intersect with their sexual identities." Statements such as these render invisible the ways that race and racism intersect with other identities to constitute participants' lives. What may be a salient part of how one experiences their gender and sexuality is erased.

In addition, some authors recognized the differences in marginalization for queer and trans people of color and even reported race/ethnicity in the sample while avoiding 
Journal Committed to Social Change on Race and Ethnicity | Volume 7, Issue 2 | 2021

a meaningful engagement with race and racism. One article included the following in their limitations section:

[w] did not attend to the specific ways in which students experiences as TGNC [trans and gender non-conforming] may have intersected with their race/ethnicity -although we do report students' race/ethnicities, which is an advancement over the only prior study on trans graduate students which did not report racial, ethnic, or sexual orientation data for participants.

Although we understand the intent of the quoted text may be to show the significance of the study through marking a unique "advancement," the mere inclusion of race/ethnicity demographic data with no contextualization still manages to avoid analysis of race and racism. We would argue that the quote is not an advancement in making meaning of the intersection of trans-ness and race due to the lack of critical engagement given to the racial/ethnic identities of participants. The quoted text suggests that the authors are aware of the importance of race, gender, and sexuality in the study of trans graduate students yet do little to make a race-explicit intervention, thus making the race/ethnicity demographic data information a cosmetic inclusion.

Related, we turned to LGBTQ+ campus climate studies and analyzed their attention to race and racism. Discussions of race appeared constantly in campus climate studies in literature reviews but failed to appear almost anywhere else. For example, when summarizing the literature on LGBTQ students and their classroom experiences, one set of authors suggested that:

[a]lthough there is little empirical research examining the effect of classroom experiences on LGBTQ student learning, development, and persistence, research on the influence of classroom climate on women and racial/ethnic minorities often suggests that the classroom climate can be unwelcoming toward women and students of color [...] 
Journal Committed to Social Change on Race and Ethnicity | Volume 7, Issue 2 | 2021

Here, we see researchers place queer and trans oppression into a lineage of scholarship on sexism and racism in higher education, suggesting a shared status of marginalization in the classroom. However, the connection stops there for many campus climate studies as race and racism fails to appear elsewhere. In this particular manuscript, beyond mentioning the sample in the study was $1 / 3$ people of color, race or racism is not named again. Thus, attention to race and racism did not inform most campus climate studies reviewed, especially in the variables included. One of the limitations to the studying of race and racism related to campus climate studies about LGBTQ+ people is the use of pre-existing data sets that do not ask intersectional questions regarding race/racism, which limits an intersectional analysis. Indeed, this may mean that the questions asked already lack attention to race/ism.

We now turn to the number of times race is named in different components of all the reviewed research articles. For instance, 56 articles named race or the racial identities of participants in the findings, discussion, or limitations sections of their papers. Of these, 19 mentioned the role of racism in participants' lived experiences. Additionally, only four carried discussions of racism or racist structures to the implications of their research. In other words, even for scholars who referred to race as a structuring force in students' lives earlier in their manuscripts, even less mentioned addressing racism in the implications of their research. These counts reflect that ways that researchers may be trained to name race are a metric of difference or to articulate limitations in a sample's lack of racial diversity, while at the same time minimizing the impact of racism. Overall, as authors, we find the naming of race to be performative: 
Journal Committed to Social Change on Race and Ethnicity | Volume 7, Issue 2 | 2021

researchers named race as a marker of difference but did not engage deeply with racial theorizing.

\section{Calls for Future Research}

One of the ways race appeared in the implication sections in several articles was via the frequent call for future research regarding students of color. Often coupled with the lack of racial diversity in the sample, particularly in quantitative studies, these calls are seemingly attentive to race given this call for future research. We provide two quotes that reflect the larger trend in this finding. Qualitative studies generally called for future research to explore the intersection of sexual orientation, gender identity, or/and race, as shown here,

As the experience of sexual orientation is necessarily informed by one's race and ethnicity as well as other identities (Bowleg, 2008), an examination of the intersectionality of race/ ethnicity and sexual orientation for engineering students is another important direction for future research (Crenshaw, 1991).

Moreover, in the following quote, authors from a quantitative study acknowledged the connection in their findings between race/ethnicity, gender, and sexual orientation while at the same time calling for future research:

[...] a relationship was found in this study between gender, race/ethnicity, and sexual orientation and faculty and staff satisfaction, future inquiries might investigate the interactions between gender and sexual orientation, as well as between race/ethnicity and sexual orientation, on students' satisfaction.

Research concerning LGB students of color is scarce (Kumashiro, 2001). Future studies can give voice and recognition to the unique experiences of LGB students of color, particularly as it relates to the perceived satisfaction of their experiences.

In this study, $27.6 \%$ of the sample were people of color and the link between perceived satisfaction and race is clear given the findings of the study. And, while the authors do 
Journal Committed to Social Change on Race and Ethnicity | Volume 7, Issue 2 | 2021

include these findings that name race as related to satisfaction, beyond the quoted text there is no attention to race in the implication section.

Rather, the number of people of color are deemed not high enough or significant for inquiry by quantitative studies or authors simply chose not to generate analysis related to race and racism. These colorblind practices flattening people of color experiences not only into a large people of color group, erasing the nuances of racial specificity, but also into larger white queer and trans experiences. This colorblind approach is problematic as it shows a willingness to use people of color's experiences where convenient for the inquiry of the author while erasing the importance of race and racism.

In sum, while we find it appropriate to name the limitations of a study because of its lack of non-white racial diversity and call for more nuanced research that centers queer and trans people of color. However, researchers fail to use these opportunities to reflect on white and whiteness as racial projects informed their studies or impacted their data collection. This forwards white as raceless and regulates people of color as the only communities having a race which in turn reproduces racism and white supremacy. Understandings of White and Whiteness

In that vein, 68 out of the 97 articles named "white" or "Caucasian" as a race in the study. In this way, white racial identities did not go unnamed or assumed to be the default. However, whiteness as a structuring force went unnamed or under-examined overwhelmingly. Only four out of the 97 articles included whiteness as a feature of analysis. One mentioned whiteness in their positionality: "The first author has come to a greater understanding and salience of their mixed race identity while simultaneously 
Journal Committed to Social Change on Race and Ethnicity | Volume 7, Issue 2 | 2021

interrogating their Whiteness." Additionally, in another article, the author named whiteness to contextualize queer students of color experiences while navigating campus environments: "Though Nicole detailed how she found belonging with her partner and friend group, she did not find belongingness on campus because of the sea of Whiteness present." And still, whiteness went unnamed as a system, and the few times that it was, authors provided no working definition. In one particular study, whiteness is even included in one of the research questions with no definition given nor does whiteness inform the analysis of the study.

In many ways, this lack of defining white and whiteness reproduces whiteness as the assumed default and therefore not needing interrogation. Just as a white institutional presence shapes college environments, messages, and practices around white cultural norms (Gusa, 2010), this lack of entanglement may lurk within the very scholarship on LGBTQ+ students. Once again, we noticed little attention given to race and racism beyond surface-level engagement. These patterns suggest that authors are naming white as a racial category while little attention is given to making meaning of whiteness. This is paired with the reality that only three studies emerged in these journals that were named as taking place at a Minority-Serving Institution (MSI), specifically at Historically Black Colleges and Universities (see Ford, 2015; Harris, 2014; Patton, 2011), showing how whiteness is replicated through a colorblind mentality both in the lack of theorization of whiteness and the inattention to settings that serve students of color (either as a historical mission or due to racial composition). 
Journal Committed to Social Change on Race and Ethnicity | Volume 7, Issue 2 | 2021

\section{Discussion}

Guided by a conceptual framework blending Bonilla-Silva (2014) notion of colorblindness and queer of color perspectives (Ferguson, 2004; Johnson \& Henderson, 2005), the present study reveals a dangerous pattern that is omnipresent in LGBTQ+ research in postsecondary education. Although scholars have contributed to a rise in literature that centers LGBTQ+ people (Lange et al., 2019), providing important information to professionals about how heterosexism and trans oppression is pervasive on college campuses, this same body of research is not attentive to the role that systems like anti-Blackness, whiteness, and settler colonialism play in structuring the lives of LGBTQ+ individuals. Consequently, this project helps to illuminate the ways these systems go unnamed in LGBTQ+ research in higher education, a phenomenon that mirrors how queer studies has historically excluded a substantial racial analysis in the study of queerness and transness (Ferguson, 2004; Johnson \& Henderson, 2005). The direct consequence of which is that scholars fail to showcase how heterosexism and trans oppression is constituted in conjunction with racism and does not exist separately from it, thus potentially having adverse impacts on the work of institutional agents on college campuses.

To begin, the findings of this critical summative content analysis revealed mixed results when it came to the use of race-explicit frameworks. Although 21 of the articles reviewed employed what we as authors would consider theories that attend to race, there were two cases in which the researchers did not acknowledge the framework's potential to investigate matters of racism. Thus, in contrast to Harper's (2012) findings that researchers were not using critical race perspectives in higher education studies, 
Journal Committed to Social Change on Race and Ethnicity | Volume 7, Issue 2 | 2021

this insight showcases that even those who do limit their potential. Not only do these two studies potentially point to a lack of engagement with the interdisciplinary aspects of these frameworks (Duran et al., 2020), but from a colorblind standpoint (Bonilla-Silva, 2014), these manuscripts erase how a racial analysis was key to the theory's dismantling of heterosexism and trans oppression. In doing so, these authors further the racism that has long been present in academic knowledge production (Patton, 2016) because they sanitize theories that could have unearthed matters of race. Moreover, these articles' lenses indicate a lack of attention to the complexities of racial analyses, mirroring scholarship in higher education that erases the nuances of anti-Blackness and settler colonialism (Stewart, 2019a).

Aside from findings related to study design, our analysis also illustrates how scholars interested in LGBTQ+ topics in higher education minimize attention to race and racism despite highlighting this in their samples or in quotes from their participants. Like Johnston-Guerrero (2017) indicated, the very decisions that people make when constructing their studies can further racism. For instance, although a number of studies named participants' white identities, they failed to explicate how these students' racial identities affected their campus experiences. In short, these students were simply queer and/or trans; they were not white queer and/or trans people. By not marking how whiteness bestowed these students with certain immunities from racial discrimination, scholars fail to challenge the whiteness that predominates LGBTQ+ communities. This phenomenon is still present even when researchers named those experiences may differ based on race, as was the case for a number of studies. Though in these moments they call attention to the ways that queer and trans people of color may 
Journal Committed to Social Change on Race and Ethnicity | Volume 7, Issue 2 | 2021

experience minoritization differently as a result of their intersecting identities, they minimize the importance of bringing this to the forefront of their inquiry. Using BonillaSilva (2014) conceptualization of colorblindness, this tactic shows the performative nature of naming race without engaging its very real material implications. Although one can argue that these authors do mention race, the fact that they do not substantially take it up in their research renders these decisions cosmetic inclusions and limits its potential to investigate matters of racism.

This pattern was reproduced in the many studies that placed race as a site of future investigation despite the fact that queer and trans people of color are experiencing minoritization in the current moment (Duran, 2019; Jourian \& McCloud, 2020; Nicolazzo, 2016). Queer and trans people of color are simultaneously cast as individuals that warrant additional attention, but whose needs are implicitly placed as secondary to the larger corpus of LGBTQ+ scholarship. As a result, LGBTQ+ higher education literature replicates the very erasure that also takes place in LGBTQ+ social movements (Vaid, 2012). Tied to this, by not taking up race and racism throughout their manuscripts - and especially in implications - authors evaded the responsibility to name how practitioners must integrate a race-explicit framework in their praxis. These decisions made in academic manuscripts inevitably have implications for practice in the field.

Similar to postsecondary education broadly (Cabrera et al., 2017), LGBTQ+ research in higher education rarely interrogated the role that whiteness as a structure plays in these communities. Because articles did not name whiteness or define it when it was mentioned, it limits the ability for people to address the systemic inequalities that 
Journal Committed to Social Change on Race and Ethnicity | Volume 7, Issue 2 | 2021

result from white supremacy, resembling a form of colorblindness (Bonilla-Silva, 2014). Though research on queer and trans people of color continues to rise (Duran, 2019; Lange et al., 2019), it is troubling that scholarship has overlooked the ways that white LGBTQ+ individuals are complicit in the minoritization present in LGBTQ+ communities or how whiteness structures the lives of QTPOC. Collectively, these insights are not intended to shame the authors of these manuscripts but rather to expose how LGBTQ+ studies higher education reproduces the very erasure of race, racism, and white supremacy that exists in postsecondary education as a whole (Cabrera et al., 2017; Harper, 2012; Johnston-Guerrero, 2017; Patton et al., 2015).

\section{Moving Forward: Possibilities at This Critical Juncture}

Racism, anti-Blackness, and settler colonialism in the United States and beyond affect all people (Kendi, 2016; Tuck \& Yang, 2012; Wilder, 2013), including LGBTQ+ communities. By ignoring racial differences in study outcomes and findings, scholars participate in ideologies of absence (Stewart, 2019b), affecting present and future possibilities for intersectional change on campuses. Our findings and discussion yield several directions for scholars to consider as they research LGBTQ+ people in higher education.

First and foremost, researchers must pay greater attention to race and racism in their analysis of LGBTQ+ populations in higher education. Although not a new implication (Duran, 2019), it appears scholars interested in LGBTQ+ communities in higher education have yet to broadly take up this call. Though acknowledging race in one's sample or participant pool is an important step, the road to meaningful inclusion in scholarship remains long; one step will not suffice. While examining across-group 
Journal Committed to Social Change on Race and Ethnicity | Volume 7, Issue 2 | 2021

similarities, scholars must ask questions, add items to their research designs, and use frameworks that examine within-group differences, particularly along racial lines.

Furthermore, the use of race attentive frameworks is a key starting place to deprioritize a micro-level understanding of race and racism. Said otherwise, race attentive frameworks grapple with larger structures of racism that assume such inequality already exists rather than relying on participants' naming of such occurrences. As LGBTQ+ experiences can often be rendered as only white (Vaid, 2012), race attentive frameworks help scholars name the broader realities for LGBTQ+ people of color while not allowing white LGBTQ+ individuals' racial identities to be obscured in such analyses. We also encourage readers to be attentive to color-blindness while engaging researchers and to examine the impact of minimization of race and racism on the framing of LGBTQ research.

We also wish to highlight the near absence of interview-based research about LGBTQ+ people at Historically Black Colleges and Universities (HBCUs), Tribal Colleges and Universities (TCUs), and other Minority Serving Institutions (MSIs) in our sample. To be sure, scholars are making important interventions into higher education scholarship related to improving the experiences of LGBTQ+ people at MSIs. For example, Mobley and Johnson (2019) used critical discourse analysis to examine media coverage and reaction to Morehouse College's appropriate attire policy and the strides made to make HBCU campuses more queer-friendly. Though the study's discoursebased methodology precluded it from our sample, it remains critical to note that LGBTQ+ MSI scholarship does exist in these journals. Moreover, there are several interview-based publications outside our journal selection parameters that serve a 
Journal Committed to Social Change on Race and Ethnicity | Volume 7, Issue 2 | 2021

roadmap for future research on MSIs (e.g. Carter, 2013; Means \& Jaeger, 2013). In addition, future studies can examine why a lack of interview-based scholarship with LGBTQ+ people at HBCUs and other MSIs appear in top tier education journals. This scholarship will be central to examining, understanding, and ending anti-black, settler, and racist logics that underline the publishing process. Given the significant role MSIs play in providing access to and possibilities for students of color in postsecondary education, journal editors must take a more active role in ensuring this scholarship reaches the high-tier journals we included in our analysis. This is imperative if scholars and practitioners wish to address anti-Blackness, settler colonialism, queer and trans oppression, and their intersections as discourses about race and racism are incomplete without the experiences of LGBTQ people who study and work at MSIs.

We also challenge scholars to stop relegating projects that aim to be more inclusive of queer and trans people of color (QTPOC) and racialized perspectives to future directions sections of articles. Though we do not advocate that every study of LGBTQ+ people must include a racialized analysis, our analysis revealed a trend that positioned research projects on race, racism, and LGBTQ+ communities to a future project. Another study could follow researchers' lineage of work: have they taken up their own calls for racial analysis posed in previous articles? What might these genealogies tell us about who scholars believe should take up these projects? Is this intersecting analysis a part of everyone's work or is it a preference for some scholars over others? If we as scholars are to be attentive to race and racism in LGBTQ+ scholarship, we must match our words with our deeds and not rely on queer and trans scholars of color to do this work. 
Journal Committed to Social Change on Race and Ethnicity | Volume 7, Issue 2 | 2021

Not only do systems of power and oppression structure the lives of QTPOC but also white queer and trans people. Though queer and trans students are minoritized on college campuses, this does not mean these students' experiences of dominance should be left uninterrogated. In our study sample, some authors attended to a racial analysis of QTPOC experiences. Less analysis and attention were given to white students and investigations of whiteness in study samples and participant pools. Given the rise in studies examining whiteness in higher education (e.g., Cabrera et al., 2017; Foste, 2020; Tevis, 2020), scholars may pursue empirical investigations of white queer and trans students' simultaneous understanding of privilege and marginalization. For instance, some scholars point out that white students are the primary beneficiaries of safe zone curricula common on campuses (Fox, 2007; Fox \& Ore, 2010). Researchers like schneider and Nicolazzo (2020) employed critical discourse analysis to understand their roles as white educators who use critical pedagogies in their teaching. Self and Hudson (2015) interrogated the role of LGBTQ+ student services offices and the role they plant in reproducing, resisting, or transforming homonormative whiteness. Despite being few in numbers, these studies provide examples of integrating whiteness within LGBTQ+ communities and organizations that others may refer to when planning future study designs.

Lastly, in alignment with our goal of addressing larger trends in research, we encourage editors and editorial board members to resist colorblindness in the peerreview process. By engaging in colorblindness, "top tier" journals support an epistemological racism (Patton, 2016; Scheurich \& Young, 1997) that advances antiblackness, settler colonialism, and queer and trans oppression in publishing. Indeed, 
Journal Committed to Social Change on Race and Ethnicity | Volume 7, Issue 2 | 2021

journals have a responsibility to attend to how scholarship addressing racism has been excluded from its pages. Journals often employ rubrics and facilitate training for new reviewers to bring them in alignment with journal standards. Hence, how might journals better socialize reviewers to be more color-attentive in the review process? For instance, reviewers and editors might prompt authors to better name race in their samples or ask authors to reflect on the role of race and racism in LGBTQ+ communities throughout their manuscripts. For those authors that name race and racism in their literature review, how are reviewers and editors drawing attention to the lack of follow-up to this scholarship in the discussion section of their papers? Ultimately, editors and editorial boards have a great deal of authority in ushering this scholarship through publication pathways and the questions above may assist them in ensuring that LGBTQ+ research explicitly discusses issues of race and racism.

\section{Conclusion}

In this article, we sought to draw attention to how researchers who study LGBTQ+ populations in higher education consider race and racism through published studies in some of the top journals in the field. Through this analysis, we found that the scholarship reproduced many of the big picture norms seen in national discourse and organizing: a lack of attention to race and racism in the lives of LGBTQ+ people (Conrad, 2014; Vaid, 2012). And yet, we also observed a number of studies and authors who engaged in analyses of race and racism; there exists a literature base to build from in future projects and inquiries. Studying the lives and experiences of LGBTQ+ people broadly in higher education remains critical. At the same time, scholars must study the ways multiple axes of difference and oppression affect LGBTQ+ people differently. Our 
Journal Committed to Social Change on Race and Ethnicity | Volume 7, Issue 2 | 2021

critical summative content analysis demonstrates one way scholars can undertake these efforts in the future. We hope researchers begin or continue to practice critical reflexivity concerning their research designs, the questions they seek to investigate, and those that they do not. While LGBTQ+ research has come a long way, it has much further to go. 
Journal Committed to Social Change on Race and Ethnicity | Volume 7, Issue 2 | 2021

\section{References}

Bonilla-Silva, E. (2014). Racism without racists: Color-blind racism and the persistence of racial inequality in America (4th ed.). Rowman \& Littlefield.

Bowleg, L. (2008). When Black + lesbian + woman $\neq$ Black lesbian woman: The methodological challenges of qualitative and quantitative intersectionality research. Sex Roles, 59, 312-325. https://doi.org/10.1007/s11199-008-9400-z

Brockenbrough, E. (2015). Queer of color agency in educational contexts: Analytic frameworks from a queer of color critique. Educational Studies, 51(1), 28-44. https://doi.org/10.1080/00131946.2014.979929

Cabrera, N. L., Franklin, J. D., \& Watson, J. S. (2017). Whiteness in higher education: The invisible missing link in diversity and racial analysis. ASHE Higher Education Report, 42(6), 1-136. https://doi.org/10.1002/aehe.20116

Carter, B. A. (2013). "Nothing better or worse than being Black, bay, and in the band": A qualitative examination of gay undergraduates participating in historically Black college or university marching bands. Journal of Research in Music Education, 61(1), 26-43. https://doi.org/10.1177/0022429412474470

Cohen, C. (1997). Punks, bulldaggers, and welfare queens: The radical potential of queer politics? GLQ: A Journal of Gay and Lesbian Studies, 3(4), 437-465. https://doi.org/10.1215/10642684-3-4-437

Conrad, R. (Ed.) (2014). Against equality: Queer revolution, not mere inclusion. AK Press.

Crenshaw, K. (1989). Demarginalizing the intersection of race and sex: A Black feminist critique of antidiscrimination doctrine, feminist theory, and antiracist politics. University of Chicago Legal Forum, 8(1), 139-167. https://chicagounbound.uchicago.edu/uclf/vol1989/iss $1 / 8$

Dancy, T. E., Edwards, K. T., \& Davis, J. E. (2018). Historically white universities and plantation politics: Anti-blackness and higher education in the Black Lives Matter era. Urban Education, 53(2), 176-195. https://doi.org/10.1177/0042085918754328

Driskill, Q-L. (2016). Asegi stories: Cherokee queer and two-spirit memory. University of Arizona Press.

Dumas, M. J. (2016). Against the dark: Antiblackness in education policy and discourse. Theory into Practice, 55(1), 11-19. https://doi.org/10.1080/00405841.2016.1116852

Duran, A. (2019). Queer and of color: A systematic literature review on queer students of color in higher education. Journal of Diversity in Higher Education, 12(4), 390400. https://doi.org/10.1037/dhe0000084

Duran, A., Blockett, R. A., \& Nicolazzo, Z. (2020). An interdisciplinary return to queer and trans* studies in higher education: Implications for research and practice. In L. W. Perna (Ed.), Higher education: Handbook of theory and research (Vol. 35, pp. 1-64). Springer. https://doi.org/10.1007/978-3-030-31365-4_9

Ferguson, R. A. (2004). Aberrations in Black: Toward a queer of color critique. University of Minnesota Press. 
Journal Committed to Social Change on Race and Ethnicity | Volume 7, Issue 2 | 2021

Ford, O. (2015). From navigation to negotiation: An examination of the lived experiences of Black gay male alumni of historically Black colleges and universities. Journal of Homosexuality, 62(3), 353-373. https://doi.org/10.1080/00918369.2014.972814

Foste, Z. (2020). The enlightenment narrative: White student leaders' preoccupation with racial innocence. Journal of Diversity in Higher Education, 13(1), 33-43. https://doi.org/10.1037/dhe0000113

Fox, C. O. (2007). From transaction to transformation: (En)countering White heteronormativity in "safe spaces". College English, 69(5), 496-511.

Fox, C. O., \& Ore, T. E. (2010). (Un)Covering normalized gender and race subjectivities in LGBT "safe spaces". Feminist Studies, 36(3), 629-649. https://www.jstor.org/stable/27919125

Graves, K. (2018). The history of lesbian, gay, bisexual, transgender, queer issues in higher education. In M. B. Paulsen (Ed.), Higher education: Handbook of theory and research (Vol. 33, pp. 127-173). Springer. https://doi.org/10.1007/978-3-31972490-4 4

Gusa, D. L. (2010). White institutional presence: The impact of whiteness on campus climate. Harvard Educational Review, 80(4), 464-489. https://doi.org/10.17763/haer.80.4.p5j483825u110002

Harper, S. R. (2012). Race without racism: How higher education researchers minimize racist institutional norms. The Review of Higher Education, 36(1), 9-29. https://doi.org/10.1353/rhe.2012.0047

Harris, J. C., \& Patton, L. D. (2019). Un/doing intersectionality through higher education research. The Journal of Higher Education, 90(3), 347-372. https://doi.org/10.1080/00221546.2018.1536936

Harris, L. N. (2014). Black, queer, and looking for a job: An exploratory study of career decision making among self-identified sexual minorities at an urban historically Black college/university. Journal of Homosexuality, 61(10), 1393-1419.

Hsieh, H-F., \& Shannon, S. E. (2005). Three approaches to qualitative content analysis. Qualitative Health Research, 15(9), 1277-1288. https://doi.org/10.1177/1049732305276687

Johnson, E. P., \& Henderson, M. (Eds.) (2005). Black queer studies: An anthology. Duke University Press.

Johnston-Guerrero, M. P. (2017). The (mis)uses of race in research on college students: A systematic review. Journal Committed to Social Change on Race and Ethnicity (JCSCORE), 3(1), 6-41. https://doi.org/10.15763/issn.26422387.2017.3.1.5-41

Jones, S. R., Torres, V., \& Arminio, J. (2014). Negotiating the complexities of qualitative research in higher education: Fundamental elements and issues (2nd ed.). Routledge.

Jourian, T.J., \& McCloud, L. (2020). “I don't know where I stand”: Black trans masculine students' re/de/constructions of Black masculinity. Journal of College Student Development, 61(3), 733-749. https://doi.org/10.1353/csd.2020.0072

Kendi, I. X. (2016). Stamped from the beginning: A definitive history of racist ideas in America. Nation Books. 
Journal Committed to Social Change on Race and Ethnicity | Volume 7, Issue 2 | 2021

Kortegast, C. A., Jaekel, K., \& Nicolazzo, Z. (2020). Thirty years of LGBTQ prepublication knowledge production in higher education research: A critical summative content analysis of ASHE conference sessions. Journal of Homosexuality. Advance online publication. https://doi.org/10.1080/00918369.2019.1702351

Krippendorff, K. (2004). Content analysis: An introduction to its methodology (2nd ed.). Sage.

Krutzsch, B. (2019). Dying to be normal: Gay martyrs and the transformation of American sexual politics. Oxford University Press.

Kumashiro, K. K. (2001). Queer students of color and antiracist, antiheterosexist education: Paradoxes of identity and activism. In K. K. Kumashiro (Ed.), Queer students of color and anti-oppressive education (pp. 1-26). Rowman \& Littlefield.

Lange, A. C., Duran, A., \& Jackson, R. (2019). The state of LGBT and queer research in higher education revisited: Current academic houses and future possibilities. Journal of College Student Development, 60(5), 511-526. http://doi.org/10.1353/csd.2019.0047

Lee, R., Ahtone, T., Pearce, M. Goodluck, K., McGhee, G., Leff, C., Lanpher, K., \& Salinas, T. (2020, March 30). Land-grab universities. High Country News. https://www.landgrabu.org/

Means, R. D. \& Jaeger, J. A. (2013). Black in the rainbow: "Quaring" the Black gay male student experience at historically Black universities. Journal of African American Males in Education, 4(2), 46-62. https://jaamejournal.scholasticahq.com/article/18442-black-in-the-rainbowquaring-the-black-gay-male-student-experience-at-historically-black-universities

Mitchell, D., Jr., Hardley, J., Jordan, D, \& Couch, M. (2014). Journals in the field of higher education: A racial analysis. Journal of Research Initiatives, 1(2), 1-10. https://digitalcommons.uncfsu.edu/jri/vol1/iss2/2

Mobley, S. D., Jr., \& Johnson, J. M. (2019). "No pumps allowed": The "problem" with gender expression and the Morehouse College "appropriate attire policy." Journal of Homosexuality, 66(7), 867-895. https://doi.org/10.1080/00918369.2018.1486063

Nash, J. C. (2019). Black feminism reimagined: After intersectionality. Duke University Press.

Neuendorf, K. A. (2017). The content analysis guidebook (2nd ed.). Sage.

Nguyen, T. H. (2014). A view from the bottom: Asian American masculinity and sexual representation. Duke University Press.

Nicolazzo, Z. (2016). "It's a hard line to walk": Black non-binary trans* collegians' perspectives on passing, realness, and trans ${ }^{\star}$-normativity. International Journal of Qualitative Studies in Education, 29(9), 1173-1188. https://doi.org/10.1080/09518398.2016.1201612

Omi, M., \& Winant, H. (2015). Racial formation in the United States (3rd ed.). Routledge.

Patton, L. D. (2011). Perspectives on identity, disclosure, and the campus environment among African American gay and bisexual men at one historically Black college. Journal of College Student Development, 52(1), 77-100. https://doi.org/10.1353/csd.2011.0001 
Journal Committed to Social Change on Race and Ethnicity | Volume 7, Issue 2 | 2021

Patton, L. D. (2016). Disrupting postsecondary prose: Toward a critical race theory of higher education. Urban Education, 51(3), 315-342.

Patton, L. D., Harper, S. R., \& Harris, J. (2015). Using critical race theory to (re)interpret widely studied topics related to students in US higher education. In A. M. Martínez-Alemán, B. Pusser, E. M. Bensimon (Eds.), Critical approaches to the study of higher education (pp. 193-219). John Hopkins University Press.

Rankin, S., Garvey, J. C., \& Duran, A. (2019). A retrospective of LGBT issues on US college campuses: 1990-2020. International Sociology, 34(4), 435-454. https://doi.org/10.1177/0268580919851429

Renn, K. A. (2010). LGBT and queer research in higher education: The state and status of the field. Educational Researcher, 39(2), 132-141. https://doi.org/10.3102/0013189X10362579

Scheurich, J. J. \& Young, D. M. (1997). Coloring epistemologies: Are our research epistemologies racially biased? Educational Researcher, 26(4), 4-16. https://doi.org/10.2307/1176879

schneider, f. j. \& Nicolazzo, Z. (2020). Whiteness and antiracist pedagogy: A critical discourse analysis of two trans* educators' classroom experiences. Whiteness and Education. https://doi.org/10.1080/23793406.2020.1734963

Self, J. M., \& Hudson, K. D. (2015). Dangerous waters and brave space: A critical feminist inquiry of campus LGBTQ centers. Journal of Gay \& Lesbian Social Services, 27(2), 216-245. https://doi.org/10.1080/10538720.2015.1021985

Snorton, C. R. (2017). Black on both sides: A racial history of trans identity. University of Minnesota Press.

Spade, D. (2011). Normal life: Administrative violence, critical trans politics, and the limitations of law. South End Press.

Stein, S. (2020). A colonial history of the higher education present: Rethinking landgrant institutions through processes of accumulation and relations of conquest. Critical Studies in Education, 61(2), 212-228. https://doi.org/10.1080/17508487.2017.1409646

Stewart, D-L. (2019a). Envisioning possibilities for innovations in higher education research on race and ethnicity. Journal Committed to Social Change on Race and Ethnicity (JCSCORE), 5(1), 7-32. https://doi.org/10.15763/issn.26422387.2019.5.1.6-32

Stewart, D-L. (2019b). Ideologies of absence: Anti-blackness and inclusion rhetoric in student affairs practice. Journal of Student Affairs, 28, 15-30. https://sahe.colostate.edu/ideologies-of-absence/

Tevis, T. (2020). Exploring whether white male postsecondary presidents respond to racism. Whiteness and Education, 5(1), 91-111. https://doi.org/10.1080/23793406.2019.1711150

Tuck, E., \& Yang, K. W. (2012). Decolonization is not a metaphor. Decolonization: Indigeneity, Education, \& Society, 1(1), 1-40. https://jps.library.utoronto.ca/index.php/des/article/view/18630

Vaid, U. (2012). Irresistible revolution: Confronting race, class and the assumptions of LGBT politics. Magnus Books.

Wilder, C. S. (2013). Ebony \& ivy: Race, slavery, and the troubled history of America's universities. Bloomsbury Press 